\title{
Population study of the fan shell Pinna nobilis L. in Malo and Veliko Jezero of the Mljet National Park (Adriatic Sea)*
}

\author{
TIHANA ̌̌ SLETIĆ ${ }^{1}$ and MELITA PEHARDA ${ }^{2}$ \\ ${ }^{1}$ Croatian Malacological Society, Ratarska 61, 10000 Zagreb, Croatia. \\ E-mail: tihana.siletic@zg.hinet.hr \\ ${ }^{2}$ Institut of Oceanography and Fisheries, Šetalište Ivana Meštrovića 63, 21000 Split, Croatia.
}

\begin{abstract}
SUMMARY: Although previous studies have noted the presence of the bivalve Pinna nobilis Linnaeus, 1758 in Mljet National Park, there is a lack of basic knowledge of this endangered species. The present study was initiated as part of a long-term investigation of $P$. nobilis density and growth with the aim of gaining a better understanding of this species' population dynamics, as well as evaluating the efficiency of protection measures of $P$. nobilis in Mljet National Park. Density, population structure, growth of tagged individuals and epibionts on $P$. nobilis were studied using SCUBA diving in 1998 and 2000 along four transects in Mljet inlets, Adriatic Sea. The density of $P$. nobilis ranged from $0.20 \mathrm{ind} / \mathrm{m}^{2}$ on transect MLJ-9 in Malo Jezero in 1998 to $0.02 \mathrm{ind} / \mathrm{m}^{2}$ on transect MLJ-5 in Veliko Jezero in 2000. Individuals measured in 1998 were significantly smaller than those measured in 2000. Growth curves were constructed from data collected by tagging and re-measuring 47 individuals. A decrease in density along some of the transects and the disappearance of 24 tagged individuals in 2000 is suggestive of poaching. The results of the present study indicate recovery of the $P$. nobilis population in Mljet lakes, but also provide evidence for the illegal removal of this protected species.
\end{abstract}

Key words: Pinna nobilis, bivalve, population study, Mljet National Park.

RESUMEN: Estudio de las poblaciones de nacra Pinna nobilis L. en Malo y Veliko Jezero en el Parque Nacional MLJET (MAR ADRIÁTICO). - A pesar de que estudios previos han reportado la presencia del bivalvo Pinna nobilis Linnaeus, 1758 en el Parque Nacional Mljet, exista una falta de conocimiento básico sobre esta especie amenazada. El presente estudio se inició como parte de un proyecto de investigación a largo plazo sobre la densidad y crecimiento de $P$. nobilis con la intención de obtener una mayor comprensión de la dinámica de poblaciones de esta especie, así como para evaluar la eficiencia de las medidas de protección de P. nobilis en el Parque Nacional Mljet. Densidades, estructura de población, crecimiento de individuos marcados y epibiontes sobre $P$. nobilis fueron estudiados mediante equipos de inmersión autónoma en 1998 y 2000 a lo largo de cuatro transectos en la zona de Mljet, Mar Adriático. Las densidades de P. nobilis oscilaron entre $0.20 \mathrm{ind} / \mathrm{m}^{2}$ en el transecto MLJ-9 en Malo Jezero en 1998 y 0.02 ind $/ \mathrm{m}^{2}$ en el transecto MLJ-5 en Veliko Jezero en 2000. Los individuos medidos en 1998 fueron significativamente más pequeños que los medidos en 2000. Se construyeron curvas de crecimiento a partir de datos obtenidos por marcado de 47 individuos. Una disminución de las densidades a lo largo de alguno de los transectos y la desaparición de 24 individuos marcados en 2000 sugieren la presencia de capturas ilegales. Los resultados del presente estudio indican una recuperación de la población de $P$. nobilis en los lagos de Mljet, pero también proporcionan evidencia de capturas ilegales de esta especie protegida.

Palabras clave: Pinna nobilis, bivalvo, estudio de poblaciones, Parque Nacional Mljet. 


\section{INTRODUCTION}

The fan shell Pinna nobilis Linnaeus, 1758 is a Mediterranean endemic bivalve that is widespread along the eastern coast of the Adriatic Sea. It is the largest Mediterranean bivalve and individuals of up to $120 \mathrm{~cm}$ have been recorded (Zavodnik et al., 1991). In Croatia, a law has existed since 1977 to protect the species (Narodne novine, 23/1977).

Fan mussels prefer fine, well-sorted sandy sediments or sand partly mixed with mud, overgrown by meadows of marine phanerogams Posidonia oceanica (Linnaeus) Delile and Cymodocea nodosa (Ucria) Aschers (Gamulin-Brida, 1974; Zavodnik et al., 1991). Although there are several papers referring to Pinna nobilis in France and Spain which describe the ecology (Combelles et al., 1986; Gaulejac and Vicente, 1990; Butler et al., 1993), morphometry, growth and age (Moreteau and Vicente, 1982; Garcia March and Ferrer Ferrer, 1995; Richardson et al., 1999), and gametogenesis and reproduction (Gaulejac, 1995; Gaulejac et al., $1995 \mathrm{a}, \mathrm{b}$ ), only a few publications refer to the morphology and ecology of $P$. nobilis in the Adriatic Sea (Mihailinović, 1955; Zavodnik, 1967; Zavodnik et al., 1991). The first details concerning the growth of this species in the Adriatic are given by Mihailinović (1955), following experimental aquaculture of $P$. nobilis in Mali Ston Bay. Zavodnik (1967) contributed to the knowledge of fan mussel ecology in the northern Adriatic with special attention to epibionts, whilst Zavodnik et al. (1991) gave a review of knowledge on $P$. nobilis in the entire eastern Adriatic including data on its spatial distribution.

Previous studies conducted in Mljet National Park (Draganović, 1980; Orepić et al., 1997), south Adriatic Sea, have shown that this area is an especially important habitat for $P$. nobilis and could be used for the detailed study of population structure and density. The most important features of Mljet National Park are two lake-like inlets, Malo Jezero and Veliko Jezero (Eng. Small Lake and Great Lake), which are located on the western part of Mljet island and are a natural phenomena of karstic depressions (Wunsam et al., 1999). Malo Jezero is connected with Veliko Jezero through a shallow and narrow channel, which is in turn connected to the surrounding open sea through a somewhat deeper and wider channel. Detailed descriptions of the environmental conditions in these two inlets are given in Benović et al. (2000).
The presence of $P$. nobilis in Mljet inlets was recorded for the first time during an investigation of benthic communities made by Draganović (1980). During his research, he noted that $P$. nobilis occured in Veliko Jezero, but did not find a single individual in Malo Jezero. P. nobilis was not further mentioned in the scientific literature related to this area until almost twenty years later when Orepić et al. (1997) and Žerlić (1999) conducted a new benthic survey in Mljet National Park. These authors found pinnids on 15 SCUBA transects in Malo and Veliko Jezero, with an especially dense population in Malo Jezero. High $P$. nobilis density and its spatial distribution have also been noted in Malo Jezero by Peharda (2000). A population recovery in Malo Jezero following the study of Draganović (1980) can be attributed to the legal protection of $P$. nobilis under the category of an endangered species (Narodne novine, 23/1977).

However, none of these studies attempted to measure in situ the size of $P$. nobilis and to describe the population structure and growth parameters that are important for understanding this species' ecology in this region, as well as in other parts of the Mediterranean. In addition, by gaining a better insight into the ecology of $P$. nobilis these data can then be used for the evaluation and improvement of protection measures for this endangered species. Since $P$. nobilis is already legally protected and high densities occur in Mljet National Park, the area is a unique natural laboratory for such studies.

\section{MATERIALS AND METHODS}

The study was conducted using SCUBA diving during the summers of 1998 and 2000 at two sites in Malo Jezero (Velika Priježba MLJ-9 and Glavica od mosta MLJ-25) and two in Veliko Jezero (Sv. Marija MLJ-5 and Pristanište MLJ-55) (Fig. 1). These sites were chosen according to the studies of Orepić et al. (1997) and Žerlić (1999), who both recorded significant numbers of $P$. nobilis in the areas. A 100 $\mathrm{m}$ long transect line was fixed, prior to each dive, perpendicularly to the shoreline, from the shore towards a deeper part of the inlet. A pair of divers recorded and measured (to the nearest $0.5 \mathrm{~cm}$ ) every pinnid within two metre corridors on either side of the transect line, thereby determining density of $P$. nobilis in an area of approximately $400 \mathrm{~m}^{2}$ on each transect. Position along the transect of each individual, depth, substrate type according to visual assess- 


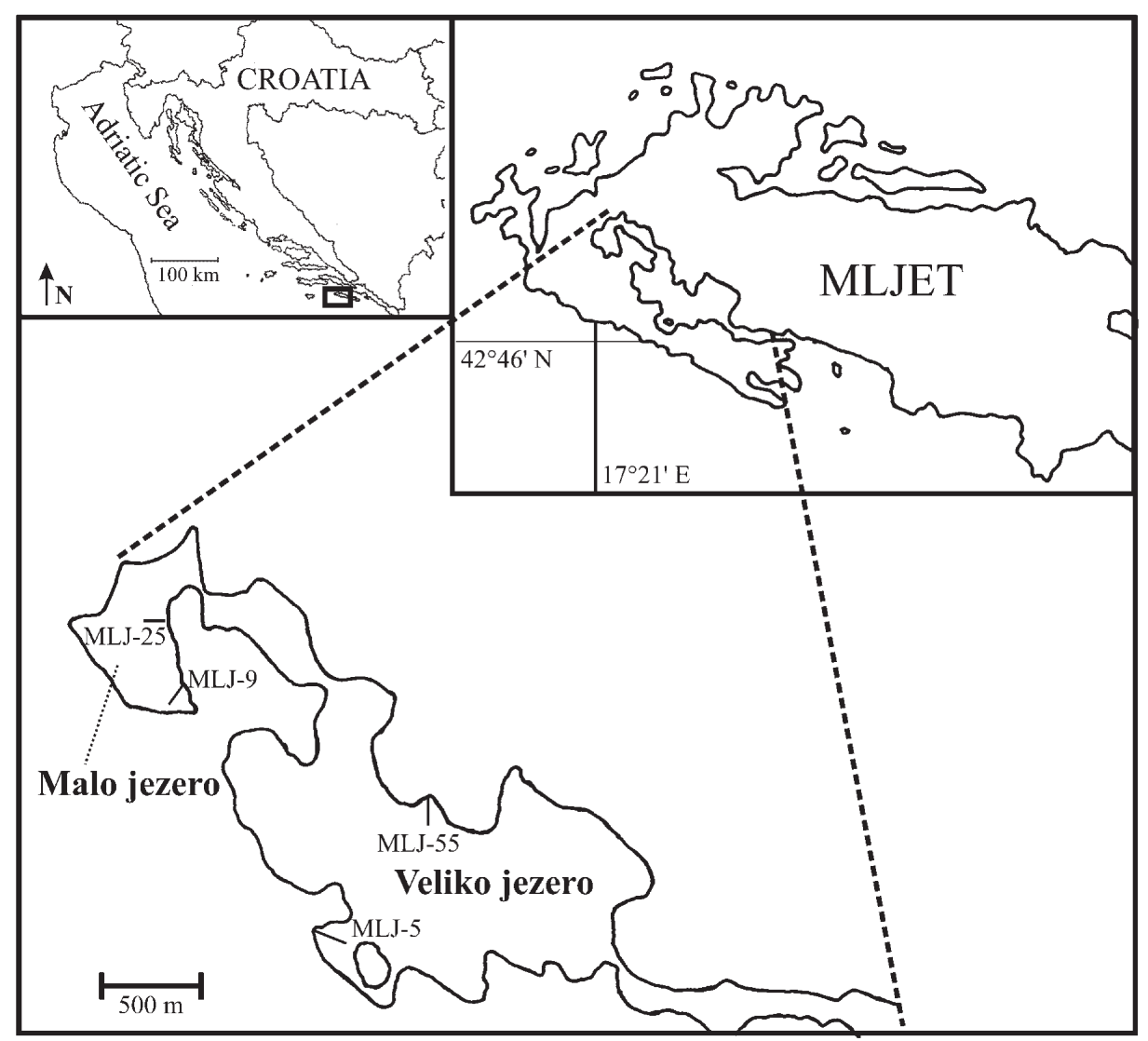

FIG. 1. - Research area in Mljet National Park with transects surveyed in Malo Jezero (MLJ-9, MLJ-25) and Veliko Jezero (MLJ-5, MLJ-55).

ment and epibionts attached to each $P$. nobilis were recorded underwater on a plastic slate. Where identification of the epibionts was in doubt, samples were collected for later laboratory analysis.

Only one dive per transect was made, except on transect MLJ-5 in 1998, for which density data were calculated from two separate dives on different occasions. Parts of transects that had rocky substrates were not taken into consideration in the calculation of pinnid density since rock is not a suitable substrate for settlement. Therefore, the actual area of the transect used in the density calculation was somewhat smaller than the $400 \mathrm{~m}^{2}$ surveyed. At transect MLJ-9 the surveyed area was $392 \mathrm{~m}^{2}$, at MLJ25 it was $388 \mathrm{~m}^{2}$, at MLJ-5 it was $380 \mathrm{~m}^{2}$ and at MLJ-55 it was $368 \mathrm{~m}^{2}$. The density of $P$. nobilis was calculated for each transect using the total number of individuals recorded along the transect divided by the actual area surveyed on the transect.

Using the technique described by Moreteau and Vicente (1982) and Garcia March and Ferrer Ferrer (1995), P. nobilis were measured in situ: the shell height above the sediment (Hs) and width of the shell at sediment level (a) were determined. Total shell height (HT) was calculated using the following equation: $\mathrm{HT}=(1.79 \mathrm{a}+0.5 \pm 0.2)+\mathrm{Hs}$, given in Garcia March and Ferrer Ferrer (1995). Although this formula was originally used for the calculation of $P$. nobilis total shell height from a different area, it was considered suitable for this study since it contains two shell size parameters which, when used together, eliminate potential problems with total shell height calculation that might occur as a result of differences in shell morphology or burial depth.

In 1998, a total of $81 P$. nobilis were marked along transects MLJ-25 and MLJ-5, one in each inlet, with numerically marked tags designed not to disturb their growth. Each numbered plastic tag was attached via a wire to a plastic stick placed into the sediment beside each pinnid. The wire from the tag was placed loosely around the base of the pinnid in order to clearly tag the individual and prevent confusion with other nearby individuals. In 2000, 57 of the 81 marked individuals (44 from MLJ-25 and 13 from MLJ-5) were located and re-measured. Due to difficulties in reading some of the numbers from the 1998 tags, caused by overgrowth, only the measurements from 47 individuals (36 from MLJ-25 and 11 
from MLJ-5) were used in the growth analysis. $P$. nobilis individuals with a total shell height size $\leq 20$ $\mathrm{cm}$ were considered juveniles according to the literature (see Combelles et al., 1986; Butler et al., 1993; Richardson et al., 1999).

Since a great deal of the pinnid size data were not normally distributed, non-parametric Mann-Whitney $U$ and Kruskal-Wallis tests were used for betweentransect and between-year comparison of total shell height (Dytham, 1999). Shell growth was analysed using a Gulland-Holt plot, where growth rates are plotted against the mean heights (Gulland and Holt, 1959). Growth parameters were estimated from a numerical value of the slope $(\mathrm{K})$ and the $\mathrm{X}$-intercept $\left(L_{\infty}\right)$. Since it is not possible to calculate a value of $t_{0}$ using this method, this constant was omitted from the von Bertalanffy equation $L_{t}=L_{\infty}\left(1-e^{-k\left(t-t_{0}\right)}\right)$ and a relative growth curve was constructed (Sparre and Venema, 1998).

\section{RESULTS}

Along the surveyed transects in Malo Jezero, Pinna nobilis were found at depths from 3 to $15 \mathrm{~m}$, on muddy sand overgrown with Cymodocea nodosa and on bare muddy substrate. In this inlet, a rocky substrate is also found along the shoreline, the $C$. nodosa meadow extends in depth from approximately 3 to 8 metres, bare sandy substrate occurs from approximately 8 to $15 \mathrm{~m}$ and muddy sediment extends from that depth to the end of the transect line. It is interesting to note that although transect MLJ-25 extended down to a depth of $21 \mathrm{~m}, P$. nobilis was not noted below $15 \mathrm{~m}$.

In Veliko Jezero, C. nodosa was found on transect MLJ-5 down to $5.5 \mathrm{~m}$, followed by muddy sand completely covered with the alga Cystoseira adriat- ica to the end of the transect line at a depth of 7 metres. On transect MLJ-55 C. nodosa was associated with $C$. adriatica from 3 to $13 \mathrm{~m}$ of depth. From 13 to $18 \mathrm{~m}$ the seabed shelves quickly, followed by a gentle slope and muddy substrate until the end of the transect line at $20 \mathrm{~m}$ depth. On this transect, $P$. nobilis was recorded up to a depth of $19 \mathrm{~m}$.

Density of $P$. nobilis recorded in 1998 was 0.20 ind $/ \mathrm{m}^{2}$ on transect MLJ-9, $0.19 \mathrm{ind} / \mathrm{m}^{2}$ on transect MLJ-25, $0.04 \mathrm{ind} / \mathrm{m}^{2}$ on transect MLJ-5 and 0.03 $\mathrm{ind} / \mathrm{m}^{2}$ on transect MLJ-55. In 2000, lower densities were recorded on transects MLJ-9 $\left(0.17 \mathrm{ind} / \mathrm{m}^{2}\right)$, MLJ-25 (0.13 ind $\left./ \mathrm{m}^{2}\right)$ and MLJ-5 (0.02 ind $\left./ \mathrm{m}^{2}\right)$, while on transect MLJ-55 a higher $P$. nobilis density $\left(0.09 \mathrm{ind} / \mathrm{m}^{2}\right)$ was recorded in comparison to 1998 . On all the surveyed transects, $P$. nobilis appeared to have a significantly denser distribution in the $C$. nodosa meadows than on bare muddy sediment or sediment covered with $C$. adriatica. Generally speaking, $P$. nobilis had a patchy distribution with a maximum of six individuals in one square metre recorded at a depth of between seven and eight metres in the $C$. nodosa meadow on transect MLJ25. Pinna nobilis density was significantly higher in Malo Jezero than in Veliko Jezero in both years of the investigation.

Besides the observed differences in densities of P. nobilis, differences in total shell height between 1998 and 2000 and between transects was noted. Sample size, mean, standard deviation and range values of total shell height according to transect and years are given in Table 1. Between-year comparison of transects showed that the total shell height of P. nobilis significantly increased at transects MLJ-9, MLJ-25 and MLJ-5 between 1998 and 2000. There was no significant change in the total shell height at station MLJ-55, where the largest individuals were recorded both in 1998 and 2000. Total shell height

TABLE 1. - Total shell height (HT) of Pinna nobilis along the transects and between-year comparison (1998/2000) of total Pinna nobilis height (HT) for each transect.

\begin{tabular}{lccccc}
\hline Transect & Year & $\mathrm{N}$ & Range $(\mathrm{cm})$ & Mean \pm st. dev. (cm) & Mann-Whitney U \\
\hline MLJ-9 & 1998 & 97 & $13.87-68.51$ & $32.36 \pm 8.34$ & 1829.5 \\
& 2000 & 65 & $7.98-55.04$ & $37.58 \pm 9.94$ & $\mathrm{p}<0.001$ \\
MLJ-25 & 1998 & 81 & $15.87-51.40$ & $32.35 \pm 6.95$ & 1121.0 \\
& 2000 & 71 & $12.48-54.98$ & $40.63 \pm 9.59$ & $\mathrm{p}<0.001$ \\
MLJ-5 & 1998 & 28 & $22.24-43.40$ & $33.76 \pm 5.67$ & 93.0 \\
& 2000 & 16 & $23.74-49.61$ & $40.36 \pm 7.41$ & $\mathrm{p}=0.001$ \\
MLJ-55 & 1998 & 31 & $23.74-75.72$ & $43.88 \pm 13.21$ & 457.0 \\
& 2000 & 30 & $19.34-77.93$ & $43.11 \pm 15.44$ & $\mathrm{p}=0.908$ \\
\hline
\end{tabular}




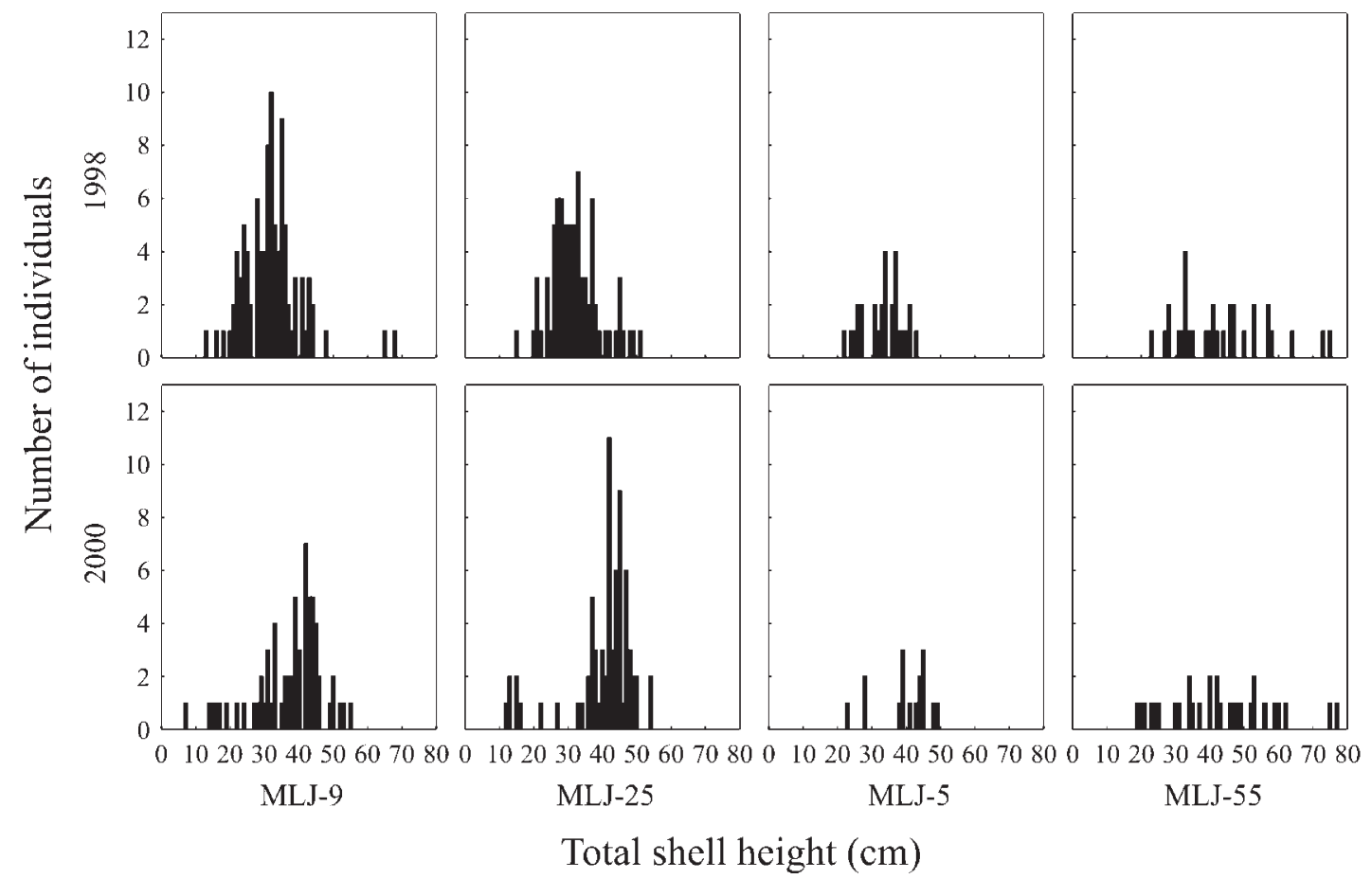

FIG. 2. - Total shell height (HT) distribution of Pinna nobilis in 1998 and 2000 according to transects.

distribution according to observation years and transects is shown in Figure 2. Transect comparison for 1998 showed that there was a significant difference in total shell height of individuals between transects (Kruskal-Wallis $\mathrm{DF}=3, \mathrm{~N}=237, \mathrm{H}=25.37, \mathrm{p}<0.001$ ); while values for transects MLJ-9, MLJ-25 and MLJ5 were very similar, total shell height values recorded on MLJ-55 were significantly higher. In 2000, there was no significant difference in total shell height between the transects (Kruskal-Wallis DF $=3$, $\mathrm{N}=182, \mathrm{H}=6.31, \mathrm{p}=0.097$ ).

In the summer of 1998 the average total shell height (HT) of the P. nobilis population calculated for all transects was $34.0 \mathrm{cms} \pm 9.2 \mathrm{~cm}$ (SD), whilst in the summer of 2000 it was $39.9 \mathrm{cms} \pm 10.8 \mathrm{~cm}$. There was a statistically significant difference between the total shell height measured in 1998 and 2000 (Mann-Whitney $U=12276.5, \mathrm{p}<0.001$ ), total shell height being significantly higher for $P$. nobilis observed in 2000. More juveniles were found in $2000(\mathrm{~N}=14)$ than in $1998(\mathrm{~N}=6)$. The total shell height distribution for all transects during 1998 and 2000 is shown in Figure 3.

Results of the tagging experiment are shown in a form of the Gulland-Holt plot in Figure 4. Von Bertalanffy growth curve constants were estimated from the linear regression line relating the mean total shell height of tagged individuals and growth

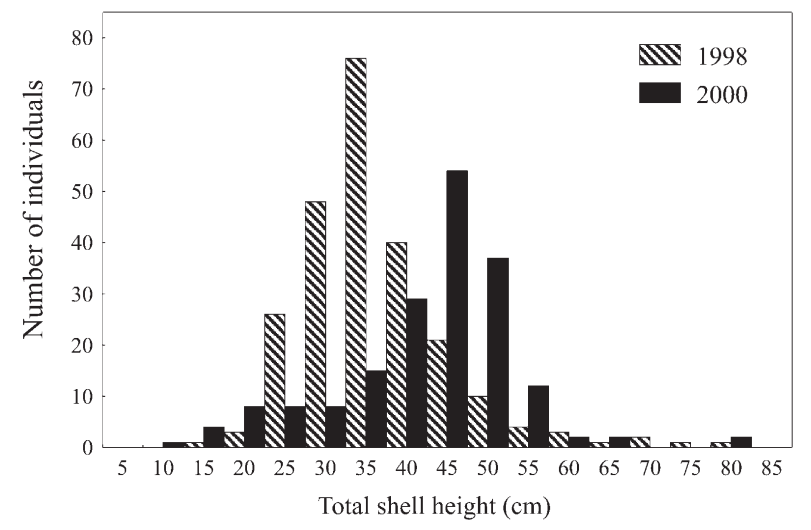

FIG. 3. - Total shell height (HT) distribution of Pinna nobilis in 1998 and 2000

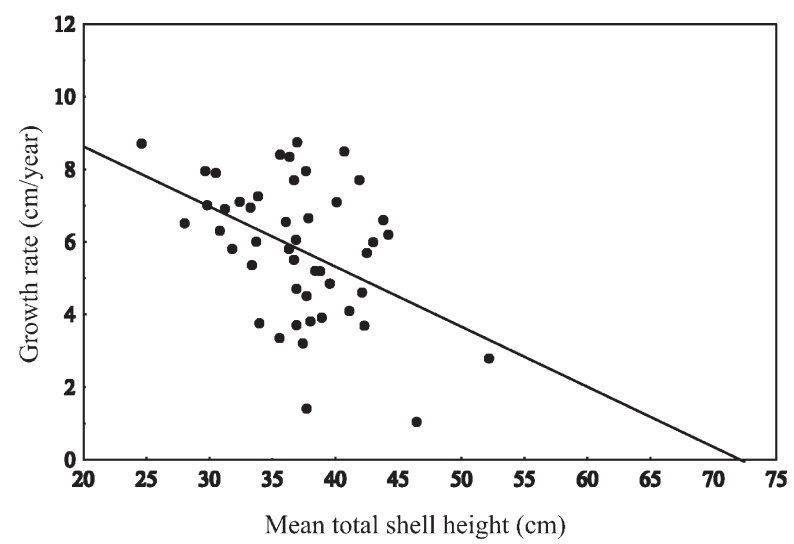

FIG. 4. - A Gulland-Holt plot between mean total shell height and growth rate (cm per year) for Pinna nobilis. 


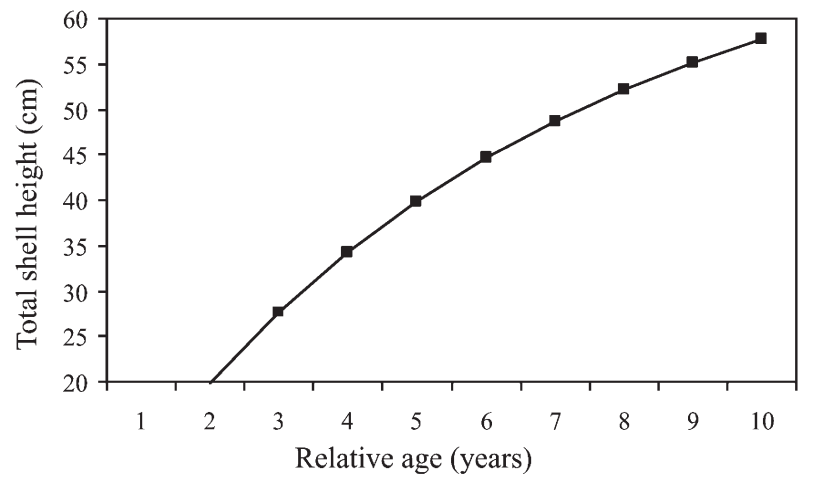

FIG. 5. - Von Bertalanffy relative growth equation for Pinna nobilis in Mljet inlets, $\mathrm{L}=72.31\left(1-\mathrm{e}^{-0.16 t}\right)$.

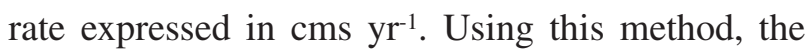
point where the line crosses $\mathrm{X}$-axis corresponds to the $L_{\propto}$ value $(72.31 \mathrm{~cm})$ and the slope of line corresponds to a $k$ value of 0.16 . A growth curve was constructed using the calculated values in the VBG equation and is presented in Figure 5. According to the equation, $P$. nobilis reaches a total shell height of approximately $11 \mathrm{~cm}$ during its first year, at age two it has a total shell height of $20 \mathrm{~cm}$, and at age three its total shell height is $28 \mathrm{~cm}$. These results are supported by additional growth data that were provided from six individuals that did not appear on the transects in 1998 but were present in 2000; these animals had a height of $12.5-16.3 \mathrm{~cm}$ and this we have assumed to correspond to a period of less than two years. According to our results, $P$. nobilis reaches a height of over $65 \mathrm{~cm}$ in about 15 years. Since the largest $P$. nobilis recorded in this study had a total shell height of $78 \mathrm{~cm}$, we can assume that this species probably lives for more than 20 years.

During the re-measuring of the pinnids in 2000 , 24 out of 81 marked pinnids were not found and therefore could not be re-measured. Along transect MLJ-25 ten individuals with their marks were found at the beginning of the transect, piled up in one small cave at one metre depth as if they had been stored; some of the individuals were still alive. Inspection of the tag numbers provided the proof that these pin-

TABLE 2. - Flora and fauna associated with Pinna nobilis during 1998 and 2000.

\begin{tabular}{|c|c|c|c|c|}
\hline Species & MLJ-9 & MLJ-25 & MLJ-5 & MLJ-55 \\
\hline \multicolumn{5}{|l|}{ ALGAE } \\
\hline Laurencia obtusa (Huds.) Lamour. & & & & + \\
\hline Polysiphonia sp. & & & & + \\
\hline Anadyomene stellata (Wulf.) & & & & + \\
\hline Valonia utricularis (Roth) C. Agardh & & & & + \\
\hline \multicolumn{5}{|l|}{ PORIFERA } \\
\hline Spirastrella cunctatrix O. Schmidt & & & & $+*$ \\
\hline Hemimycale columella (Bowerbank) & & & & + \\
\hline \multicolumn{5}{|l|}{ CNIDARIA } \\
\hline Caryophyllia sp. & & & & + \\
\hline \multicolumn{5}{|l|}{ MOLLUSCA } \\
\hline Jujubinus exasperatus (Pennant) & & + & & + \\
\hline Jujubinus striatus striatus (Linnaeus) & & & & + \\
\hline Bittium reticulatum (Da Costa) & & & + & + \\
\hline Cerithium vulgatum Bruguiere & & + & & \\
\hline Bolinus brandaris (Linnaeus) & & + & & \\
\hline Arca noae Linnaeus & $+{ }^{1}$ & + & & \\
\hline Chlamys varia (Linnaeus) & $+^{1}$ & & & \\
\hline Anomia ephippium Linnaeus & & & & 0 \\
\hline Ostrea edulis Linnaeus & $++^{1,2}$ & + & & $+*, 4,0$ \\
\hline Hiatella sp. & & & & + \\
\hline \multicolumn{5}{|l|}{ ANNELIDA } \\
\hline Pomatoceros triqueter (Linnaeus) & & & & + \\
\hline Serpula vermicularis Linnaeus & & + & & + \\
\hline Serpula sp. & & & & $t^{3}$ \\
\hline \multicolumn{5}{|l|}{ CRUSTACEA } \\
\hline Pisidia longicornis (Linnaeus) & & & & + \\
\hline \multicolumn{5}{|l|}{ TENTACULATA } \\
\hline Bugula simplex (Hincks) & & & & + \\
\hline Schizobrachiella sanguinea (Norman) & & & & + \\
\hline \multicolumn{5}{|l|}{ ECHINODERMATA } \\
\hline Coscinasterias tenuispina (Lamarck)• & & & & $+*, 5$ \\
\hline Psammechinus microtuberculatus (Blainville) & & + & & \\
\hline \multicolumn{5}{|l|}{ TUNICATA } \\
\hline Microcosmus sabatieri (Roule) & $+^{1}$ & & & \\
\hline
\end{tabular}

Legend: 0, dead shells; +, live individuals; * on dead fan shell; $\bullet$ on fan shell at sediment level; ${ }^{1}$ at 43.8 and $65.4 \mathrm{~cm}$ high fan shells; ${ }^{2}$ at 6 fan shells individuals of total height from 37.3 to $50.1 \mathrm{~cm} ;{ }^{3}$ at fan shell individuals of total height $47,53.9$ and $62.5 \mathrm{~cm} ;{ }^{4}$ at $77.9 \mathrm{~cm}$ high fan shell; ${ }^{5}$ at $30.5 \mathrm{~cm}$ high fan shell 
nids had been taken from the first 20 metres of the transect, from a depth of between 3 and $4.5 \mathrm{~m}$. At transects MLJ-5 two marks without pinnids were found still stuck in the sand, in exactly the same locations where they were placed in 1998 with no shell remains found nearby. Another five marked pinnids were missing together with their marks, and none of these pinnid shells, with or without tags, were found in the dived area.

Five species of algae and 24 invertebrate species were found attached on the living Pinna nobilis shells as epibionts (Table 2). Epibiont species noted in Malo Jezero were mostly from the phylum Mollusca (e.g. Arca noae, Ostrea edulis), whereas in Veliko Jezero they were represented with species from the phylum Porifera and Mollusca (e.g. Bittium reticulatum, Ostrea edulis), and with members of the class Polychaeta (Pomatoceros triqueter, Serpula sp.) and Bryozoa.

\section{DISCUSSION}

In the Adriatic Sea, Pinna nobilis is distributed from the shallow water $(2 \mathrm{~m})$ to $30 \mathrm{~m}$ depth (HrsBrenko, 1991; Hrs-Brenko, 1997; Zavodnik, 1967; Zavodnik et al., 1991). In Malo Jezero P. nobilis has been recorded only to depths of $15 \mathrm{~m}$ (Peharda, 2000). Results of this study agree with the previously recorded depth distribution of $P$. nobilis in Malo Jezero, and have recorded the maximum depth of $P$. nobilis in Veliko Jezero at a depth of $19 \mathrm{~m}$. The maximum depth at which $P$. nobilis has been recorded in Mljet lakes is shallower than in other investigated areas (Combelles et al., 1986; Butler et al., 1993; Žerlić, 1999) and is probably a result of the specific ecological conditions such as sediment type and oxygen saturation (Peharda, 2000). Anoxic conditions have occasionally been recorded in deeper parts of the Malo Jezero, between 19 and $25 \mathrm{~m}$, and the presence of saturated $\mathrm{H}_{2} \mathrm{~S}$ has been noted (Vuletić, 1953).

In Malo Jezero, the density of $P$. nobilis in the Cymodocea nodosa meadows appears to be higher (reaching $0.2 \mathrm{ind} / \mathrm{m}^{2}$ ) than in other areas of the Adriatic, where according to Zavodnik et al. (1991) the average $P$. nobilis density is approximately 0.1 ind $/ \mathrm{m}^{2}$. In other parts of the Mediterranean, typical P. nobilis densities are $0.01 \mathrm{ind} / \mathrm{m}^{2}$ (Combelles et al., 1986; Butler et al., 1993), which is an order of magnitude lower than in the Adriatic. Therefore, the fan mussel populations in Malo Jezero are an important and unique phenomenon that deserves special atten- tion and protection. In Veliko Jezero, $P$. nobilis densities were lower and closer to typical Mediterranean values.

Due to a lack of oceanographic data it is not possible to clearly explain the causes of such a big difference in $P$. nobilis densities between these two adjacent inlets. However, it is known that the ecological characteristics of the Mljet inlets are strongly influenced by the surrounding terrestrial area and by the restricted communication with the open sea. Further on, Malo Jezero is smaller and as such is under more influence from the shore than Veliko Jezero. It also has a more restricted exchange of water with the open sea and therefore a higher water residence time. According to Benović et al. (2000), zooplankton densities were constantly higher in Malo Jezero than in Veliko Jezero, especially during the spring and summer. The factors described above point to potentially more food sources for $P$. nobilis in Malo Jezero than in Veliko Jezero and this could be a factor influencing the difference in densities.

Although the population size of $P$. nobilis in Malo Jezero is currently substantial, the observed decrease in density along transect MLJ-25 between 1998 and 2000, together with the discovery of individuals found in a storage place, indicates possible illegal removal of $P$. nobilis and is suggestive that current protection measures are not as effective as they could be. We believe that other factors like natural mortality, caused by aging or predation, can not be considered as a main cause for the disappearance of pinnids, since our labels without the pinnids were found along transect MLJ-5 and no shells with or without scars from predators were found in the transect area or nearby. Further on, there was no sign of broken pinnid shells on the transects that would result from other human activities such as anchor damage. Therefore, we believe the major reason for the decrease in P. nobilis density is their illegal removal.

Results of the growth analysis are in general accordance with those of previous studies (Mihailinović, 1955; Moreteau and Vicente, 1982; Richardson et al., 1999). According to Richardson et al. (1999), in the Spanish Mediterranean, at Aguamarga and Rodalquilar, a two-year-old $P$. nobilis has a total shell height of $20 \mathrm{~cm}$ whilst at Carboneras at that age they are $30 \mathrm{~cm}$ in height. At eight years of age, fan mussels from Aguamarga and Rodalquilar reach a size of approximately $42 \mathrm{~cm}$ while at Carboneras they grow to over $55 \mathrm{~cm}$. In Mljet inlets, fan mussel had growth rates intermediate to those 
described for P. nobilis in Spain. Since the majority of $P$. nobilis in the Mljet inlets were less than $50 \mathrm{~cm}$ high, we conclude that the population is relatively young ( $<8$ years old). However, in order to obtain a clearer understanding of their population structure, future studies should analyse the age of selected individuals from Mljet lakes with special reference to smaller $(<20 \mathrm{~cm})$ and larger $(>50 \mathrm{~cm})$ individuals.

A smaller number of epibiont species was noted on $P$. nobilis from Malo Jezero in comparison to Veliko Jezero. This is in accordance with previous studies that described a reduction in the number of species in biocoenoses from the open sea, towards Veliko Jezero and Malo Jezero (Draganović, 1980). The number of epibiont species is apparently determined by the size of the Pinna shell (Zavodnik, 1967). The structure of epibioses noted in Veliko Jezero mostly corresponds to those noted in the North Adriatic (Zavodnik, 1967).

In conclusion, the results of the present study indicate a recovery of $P$. nobilis population in Mljet lakes, but also suggest possible illegal removal of this endangered species. This study has been initiated as part of a long-term study on the density and growth of $P$. nobilis which will enable the monitoring of the protection efficiency in Mljet National Park and is contributing to a better understanding of the population dynamics of this species.

\section{ACKNOWLEDGEMENTS}

The authors are very grateful to the Mljet National Park authorities and Atlas travel agency for providing logistic support for this study. We are indebted to Thais - the Society for Exploration and Conservation of Nature, for help and support in starting this study in 1998, as a part of a project "Marine ecology study in Mljet National Park". Special thanks to Drs D. Zavodnik and C. A. Richardson for valuable assistance with data analysis and preparation of the manuscript. The financial suport of the Ministry of Science and Technology of the Republic of Croatia is also acknowledged.

\section{REFERENCES}

Benović, A., D. Lučić, V. Onofri, M. Peharda, M. Carić, N. Jasprica and S. Bobanović-Ćolić. - 2000. Ecological characteristics of Mljet island seawater lakes (South Adriatic Sea) with special reference to medusa. Sci. Mar., 64 (Suppl 1): 197-206.

Butler, A., N. Vicente and B. de Gaulejac. - 1993. Ecology of the pterioid bivalves Pinna bicolor Gmelin and Pinna nobilis L. Mar. Life, 3 (1-2): 37-45.

Combelles, S., J.C. Moreteau and N. Vicente. - 1986. Contribution a la connaissance de l'écologie de Pinna nobilis L. (Mollusque: Eulamellibranche). Sci. Rep. Port-Cros natl. Park, Fr., 12: 29-43.

Draganović, E. - 1980. Litoralne biocenoze Mljetskih jezera i problemi njihove zaštite. M. Sc. thesis, Univ. Zagreb.

Dytham, M. - 1999. Choosing and using statistics: a biologist's guide. Blackwell Science, MPG Books Ltd, Bodmin.

Gamulin-Brida, H. - 1974. Biocénoses benthiques de la mer Adriatique. Acta Adriat., 15(9): 3-102.

Garcia March, J.R. and J. Ferrer Ferrer. - 1995. Biometría de Pinna nobilis L., 1758: una revisión de la ecuación de De Gaulejac y Vicente (1990). Bol. Inst. Esp. Oceanogr., 11(2): 175-181.

Gaulejac de, B. - 1995. Mise en évidence de l'hermaphrodisme successif à maturation asynchrone de Pinna nobilis (L.) (Bivalvia: Pterioidea). C.R. Acad. Sci. Paris (Sci vie), 318: 99-103.

Gaulejac de, B. and N. Vicente. - 1990. Ecologie de Pinna nobilis (L.) mollusque bivalve sur les côtes de Corse. Essais de transplantation et expériences en milieu contrôlé. Haliotis, 20: 83-100.

Gaulejac de, B., M. Henry and N. Vicente. - 1995a. An ultrastructural study of gametogenesis of the marine bivalve Pinna nobilis (Linnaeus 1758). I. Oogenesis. J. Moll. Stud., 61: 375-392.

Gaulejac de, B., M. Henry and N. Vicente. - 1995b. An ultrastructural study of gametogenesis of the marine bivalve Pinna nobilis (Linnaeus 1758). II. Spermatogenesis. J. Moll. Stud., 61: 393-403.

Gulland, J.A. and S.J. Holt. - 1959. Estimation of growth parameters for data of unequal time intervals. J. Conseil, Cons. Intern. L'Explo. Mer, 25(1): 47-49.

Hrs-Brenko, M. - 1991. Jestivi školjkaši Jadrana: IV. Lostura (Pinna nobilis Linnaeus). Morsko ribarstvo, 2: 47-50.

Hrs-Brenko, M. - 1997. The marine bivalve mollusks in the Kornati national park and the Dugi otok natural park (Adriatic Sea). Period. Biol., 99(3): 381-395.

Mihailinović, M. - 1955. Orijentacioni podaci o brzini rastenja losture. Morsko ribarstvo, 7(9): 238.

Moreteau, J.C. and N. Vicente. - 1982. Evolution d'une population de Pinna nobilis L. (Mollusca, Bivalvia). Malacologia, 22(1-2): 341-345.

Narodne novine 23/1977. Odluka o posebnoj zaštiti školjke plemenite periske.

Orepić, N., J. Vidmar, E. Zahtila and D. Zavodnik. - 1997. A marine benthos survey in the lakes of the National park Mljet (Adriatic Sea). Period. Biol., 99(2): 229-245.

Peharda, M. - 2000. Školjkaši (Bivalvia, Mollusca) Malog jezera otoka Mljeta. M.Sc. thesis, Univ. Zagreb.

Richardson, C.A., H. Kennedy, C.M. Duarte, D.P. Kennedy and S.V. Proud. - 1999. Age and growth of the fan mussel Pinna nobilis from south-east Spanish Mediterranean seagrass (Posidonia oceanica) meadows. Mar. Biol., 133: 205-212.

Sparre, P. and S.C. Venema. - 1998. Introduction to tropical fish stock assessment. Part 1. Manual. FAO Fisheries Tehnical Paper. No. 306.1, Rev. 2, FAO, Rome.

Vuletić, A. - 1953. Structure geologique du fond du Malo jezero et Veliko jezero sur l'isle de Mljet. Acta Adriat., 6(1): 1-63.

Wunsam, S., R. Schmidt and J. Muller. - 1999. Holocene lake development of two Dalmatian lagoons (Malo and Veliko Jezero, Isle of Mljet) in respect to changes in Adriatic sea level and climate. Palaeogeogr. Palaeoclimatol. Palaeoeco., 146: 251-281.

Zavodnik, D. - 1967. Contribution to the ecology of Pinna nobilis L. (Moll., Bivalvia) in the northern Adriatic. Thalassia Jugosl., 3(1-6): 93-103.

Zavodnik, D., M. Hrs-Brenko and M. Legac. - 1991. Synopsis on the fan shell Pinna nobilis L. in the eastern Adriatic sea. In: C.F. Boudouresque, M. Avon and V. Gravez (eds.), Les Espèces Marines à Protéger en Méditerranée. pp. 169-178. GIS Posidonie publ., Marseille, France.

Žerlić, T. - 1999. Školjkaši litoralnog područja Nacionalnog parka "Mljet". B. Sc. thesis, Univ. Zagreb.

Scient. ed.: C. Richardson 